\title{
Laboratory tests of oviposition by the African malaria mosquito, Anopheles gambiae, on dark soil as influenced by presence or absence of vegetation \\ Juan Huang1, Edward D Walker ${ }^{1,2}$, Philip E Otienoburu ${ }^{3}$, Fred Amimo ${ }^{1,3}$, John Vulule 3 and James R Miller*1
}

\begin{abstract}
Address: ${ }^{1}$ Department of Entomology, Michigan State University, East Lansing, MI 48823, USA, ${ }^{2}$ Microbiology and Molecular Genetics, Michigan State University, East Lansing, MI 48824, USA and ${ }^{3}$ Kenya Medical Research Institute, Kisumu, Kenya

Email: Juan Huang - huangju@msu.edu; Edward D Walker - walker@msu.edu; Philip E Otienoburu - otienoburu@gmail.com; Fred Amimo - amimofre@msu.edu; John Vulule - JVulule@kisian.mimcom.net; James R Miller* - miller20@msu.edu

* Corresponding author
\end{abstract}

Published: 12 October 2006

Malaria Journal 2006, 5:88 doi:10.1186/1475-2875-5-88

This article is available from: http://www.malariajournal.com/content/5/l/88

(C) 2006 Huang et al; licensee BioMed Central Ltd.

This is an Open Access article distributed under the terms of the Creative Commons Attribution License (http://creativecommons.org/licenses/by/2.0), which permits unrestricted use, distribution, and reproduction in any medium, provided the original work is properly cited.
Received: 07 June 2006

Accepted: 12 October 2006

\begin{abstract}
Background: Physical objects like vegetation can influence oviposition by mosquitoes on soil or water substrates. Anopheles gambiae $s$. I. is generally thought to utilize puddles over bare soil as its prime larval habitat and to avoid standing water populated with vegetation. In Kisian, Kenya near Kisumu, water often pools in grassy drainage areas both during and after periods of infrequent rains, when typical puddle habitats become scarce because of drying. This raised the question of whether An. gambiae has the behavioural flexibility to switch ovipositional sites when puddles over bare soil are unavailable.
\end{abstract}

Methods: To test whether presence and height of grasses influenced oviposition, wild-caught gravid An. gambiae s. I. were offered paired choices between wet, bare soil and wet soil populated with mixed grasses or grasses of differing height. No-choice tests were also conducted by giving females either grassy soil or bare soil.

Results: In choice tests, females laid four times more eggs on bare, wet soil than soil populated with grasses. However in no-choice tests, egg output was not significantly different whether grasses were present or not. Females laid significantly more eggs on soil populated with short grass than with medium, or tall grass.

Conclusion: This work shows An. gambiae s. I. has the capacity to oviposit into grassy aquatic habitats when typical puddles over bare soil are unavailable. This knowledge will need to be considered in the design and implementation of programmes aimed at reducing malaria transmission by suppression of An. gambiae s. I. immatures.

\section{Background}

Physical and chemical cues influence acceptance of ovipositional sites by mosquitoes [1-3]. Darkness and wetness are critical positive cues for Anopheles gambiae oviposition, while visual contrast strongly influences finding of prospective ovipositional sites [4,5]. Odours are not required 
for copious oviposition, however, they may increase egg output in some cases [6] and decrease it in others [7].

Physical objects like vegetation can influence oviposition on soil or water substrates [8-10]. Rice plants or glass rods inserted into seepage water reduced Anopheles culicifacies oviposition [8]. However, oviposition by Anopheles hermsi increased in accordance with the density of aquatic macrophytes (Myriophylluym aquaticum) up to 1,000 stems $\mathrm{m}^{-}$ 2 [10]. In the field, Anopheles funestus breeds mainly in marshes and swamps that contain tall grasses and other plants [11]. An. gambiae is generally thought to utilize puddles over bare soil as its prime larval habitat [12-15] and to avoid standing water populated with vegetation. However, Muirhead-Thomson [16] reported that An. gambiae deposited eggs in rice fields at all stages of vegetative maturity. More recently, Fillinger et al. [17] have strongly challenged the idea that An. gambiae avoids habitats with emergent vegetation like grasses. They and Minakawa et al. [18] provide evidence that An. gambiae can be commonly found in association with grasses. However, it is unclear whether presence of larvae in grassy habitats results from hatch of eggs placed on and around wet grasses, or whether larvae were carried there by flowing water. The question addressed in the current laboratory study was whether An. gambiae has the behavioral flexibility to oviposit on and around wet grasses both when bare soil is and is not available.

\section{Materials and methods}

\section{Mosquitoes and bioassay conditions}

Experiments were performed in the Entomology laboratory of the Kenya Medical Research Institute (KEMRI) in Kisian, Kenya using feral females aspirated from houses near Kisian from 28 April to May 28, 2004, and from 15 April and 15 May 2005. These blood-fed females were kept for two days in cardboard cups $(8 \mathrm{~cm}$ diam, $9 \mathrm{~cm}$ high) covered with wet cloth towels to provide moisture. Ten percent honey solution was also provided as an energy source. Gravid females were transferred into $60 \times$ $60 \times 60 \mathrm{~cm}$ white BugDorm-2 cages (MegaView Science Education Services Co., Taiwan) held on a lab bench near a bank of windows providing ambient nightlight. The response variable reported is total egg numbers. No detectable differences emerged in proportion of females retaining eggs. Although polymerase chain reaction was not performed on the wild-caught mosquitoes, previous samples from this area $[4,14]$ contained $>80 \%$ An. gambiae s. s. Thus, results reported here represent An. gambiae s. $l$..

\section{Statistical analysis}

Differences in egg output were analysed by paired $t$-test in

\section{Oviposition in response to wet soil populated with grass in 2004}

Experiment I: paired choice tests

Plugs of soil $(8 \mathrm{~cm}$ height $\times 8 \mathrm{~cm}$ diam.) with associated grasses were collected outside the KEMRI compound near areas supporting An. gambiae larvae. These plugs were inserted into white cups of similar dimensions; they contained a mixture of Bermuda grass (Cynodon dactylon), sedge grass (Scirpus steudneri), and Rhode grass (Chloris gayana). Grass coverage of the soil ranged from 50 to $70 \%$. Comparison cups were filled with soil taken from the same location but with no grass parts included. All the cups were saturated with tap water from a deep bore hole. A pair of cups with grass-covered vs. bare soil was offered to ca. 60 gravid females in a BugDorm-2 cage. Eleven replicates, each using a different batch of mosquitoes, were performed through time for choice tests.

\section{Experiment 2: no-choice tests}

The no-choice test was conducted (seven replicates) by providing 40 gravid females with a single ovipositional cup containing either grass-covered or corresponding bare soil. The following morning, grass stems were cut at their base and plants as well as soil were examined very thoroughly for the presence of eggs with the aid of a dissecting microscope.

\section{Oviposition in response to grasses of differing height in 2005 \\ Experiment 3: paired choice tests}

Soil plugs with grasses of differing height and corresponding bare soil were collected near the KEMRI compound. Over $90 \%$ of the soil was covered by grasses as compared to $50-70 \%$ in 2004 . Grasses were divided into three height categories: short $(1-2 \mathrm{~cm})$, medium $(13-16 \mathrm{~cm})$, and tall $(27-39 \mathrm{~cm})$. It is acknowledged that species of grasses co-varied with the height categories such that effects cannot be attributed to height alone. Each grass category, paired with its control bare soil, was offered to 20 wild-caught gravid females.

\section{Experiment 4: three-choice tests}

Thirty gravid females were offered: short, medium, and tall grasses for oviposition. This test was replicated six times using different batches of females. Samples of the grasses used were dried and stored in layers of dry paper for subsequent species confirmation. Short grasses consisted of cape clover, Trifolium burchellianum (80\%) and Cynodon dactylon (20\%); medium grasses were Cynodon dactylon (50\%) and Scirpus steudneri (50\%); and tall grasses were Chloris gayana, the most dominant grass around Kisian.

two-choice tests and no-choice tests. Differences in egg outputs in three-choice tests were calculated as a propor- 
tion of the total number of eggs laid in each cage and compared using 1-way analysis of variance (ANOVA) [19]. Means were separated by Tukey's significant difference (HSD).

\section{Results \\ Oviposition in response to wet soil populated with grass in 2004}

Experiment I: paired choice tests

Wild-caught An. gambiae females deposited four times more eggs on bare wet soil than on soil covered by grasses $(t=4.0, d f=10, P=0.002)$. Bare soil received $1,495 \pm 224$ eggs (mean \pm SEM) while grass-covered soil received 353 \pm 115 eggs.

\section{Experiment 2: no-choice tests}

Females laid $777 \pm 73$ eggs on bare soil compared to 573 \pm 145 eggs on grass-covered soil (difference not significant: $t=1.0, d f=6, P=0.35$ ). Both in choice- and nochoice tests, some eggs were laid on the leaves or stems of grasses (Figure 1).

\section{Oviposition in response to grasses of differing height in 2005}

Experiment 3: paired choice tests

Females laid many more eggs on bare soil than the soil covered with grasses of differing heights (for short grass: $t$ $=5.4, d f=5, P=0.003$; for medium grass: $t=2.6, d f=5$, $P=0.05$; for tall grass: $t=5.7, d f=5, P=0.002$ ) (Figure 2). However, 3 to $8 \%$ of the total eggs were laid on grass-covered soil when bare soil was nearby.

\section{Experiment 4: three-choice tests}

When no bare soil was present, more eggs were laid on the soil covered by short than by medium and tall grasses ( $F$ $=8.2 ; d f=2,10 ; P=0.008)$ (Figure 3 ).

\section{Discussion}

When offered a choice, An. gambiae s. l. deposited many more eggs on bare, wet soil than grass-covered soil. Under laboratory conditions, An. gambiae usually touches the ovipositional substrate briefly before sitting on the mud to deposit eggs or hovers 5 to $10 \mathrm{~cm}$ above the puddle or mud while laying eggs (Huang et al. unpublished data). Short grasses were more acceptable than medium and tall grasses when no bare soil was present. Overall, egg abundance on grass-covered soil relative to bare soil decreased from 20 to less than $8 \%$ as the density of the grasses increased from $50-70 \%$ (in 2004) to $90 \%$ (in 2005). The density and height of grasses might act as a barrier precluding females from approaching sufficiently close to touch the wet substrate or to land. The speculation is offered that, if no bare soil is available, females might persist in exploring a wet grassy site and eventually alight and oviposit. In some cases, eggs appeared to have rained

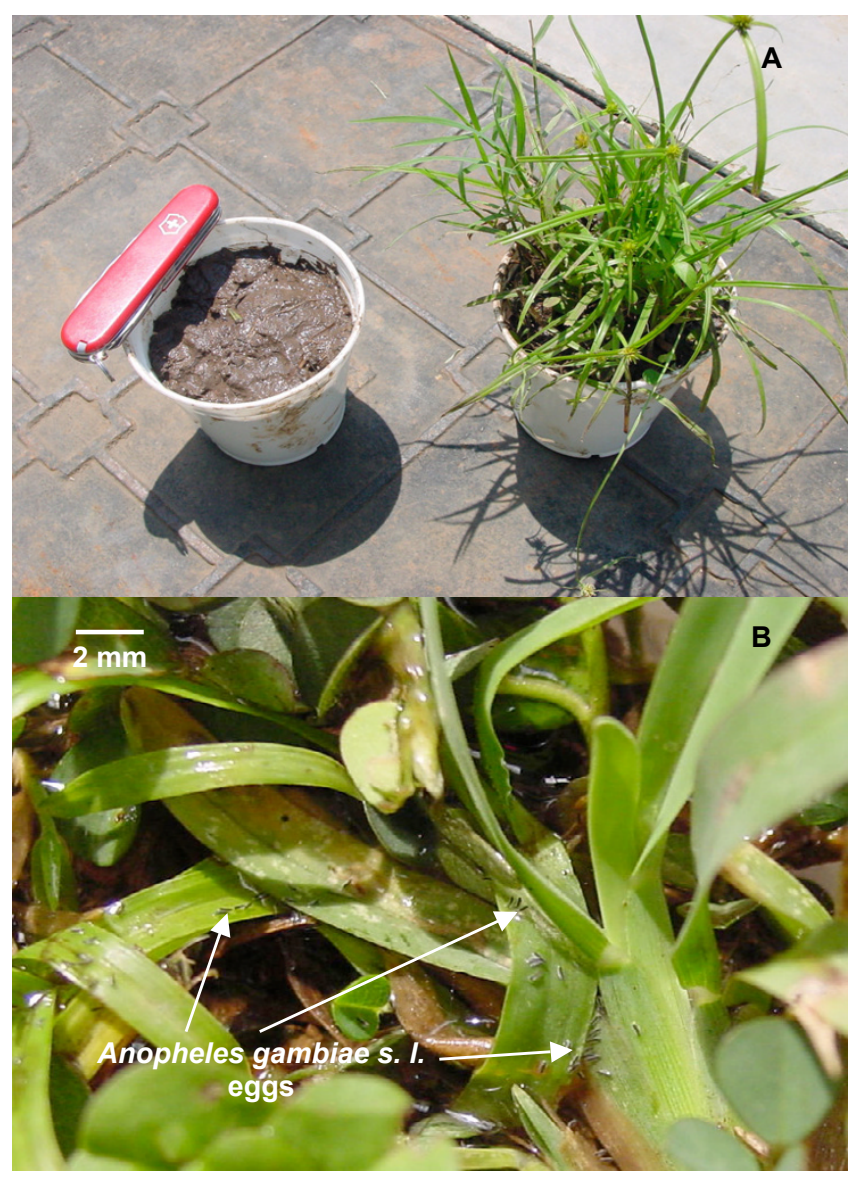

\section{Figure I}

Examples of a paired choice test between wet bare soil and wet soil populated with grasses (A), and eggs laid by Anopheles gambiae s. I. on leaves of grass growing on wet soil (B).

down upon grass leaves and axils (Figure 1). In the nochoice setting, females did not withhold eggs, but deposited copiously on whatever wet and dark resource was available. Provided they remain moist, eggs on grasses would develop [7] and, where there is a thin film of water, larvae would eclose and crawl $[20,21]$ on the grasses, perhaps reaching water beneath. Alternatively, rain could wash eggs and larvae to pools [21].

This work confirms and extends previous claims that $A n$. gambiae should be expected in rice fields [16] and other grassy habitats $[17,18]$. Females will oviposit on standing water, mud, moist sand [4], as well as mud with vegetation. This result further supports the view that An. gambiae is an ovipositional generalist [22] rather than a specialist. This malaria vector is flexible in ovipositional site selection, depending upon what ovipositional resources are available. Wet grassy zones could function as important secondary habitats when puddles over bare soil become scarce. This knowledge will need to be considered in the 


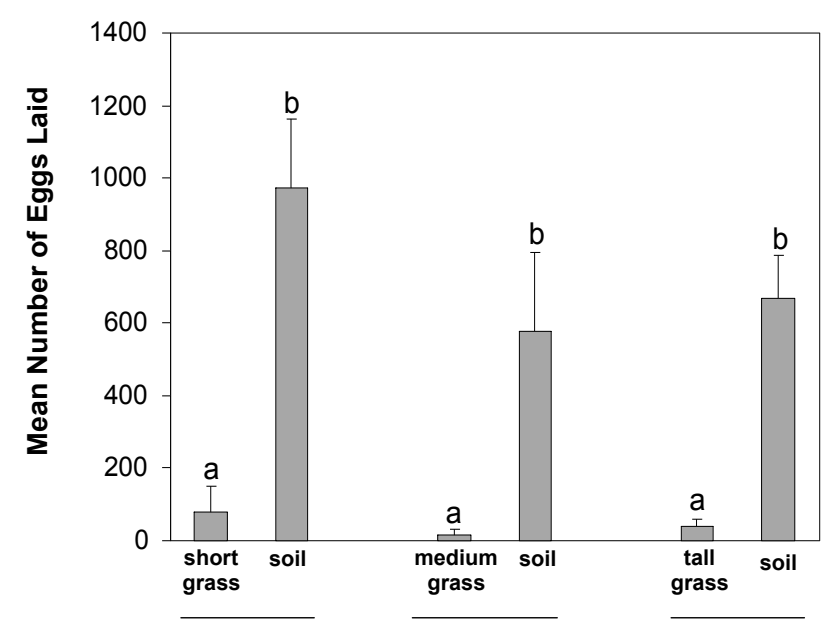

Treatments in Paired Choice Tests

\section{Figure 2}

Mean numbers of eggs by wild-caught Anopheles gambiae s. I. laid on grass-covered mud vs. its corresponding bare mud. Within a choice test, bars topped with a common letter do not differ significantly at the 0.05 level (Tukey's HSD test). Error bars = S. E. M.

design and implementation of programmes aimed at reducing malaria transmission by suppression of An. gambiae s. l. immatures.

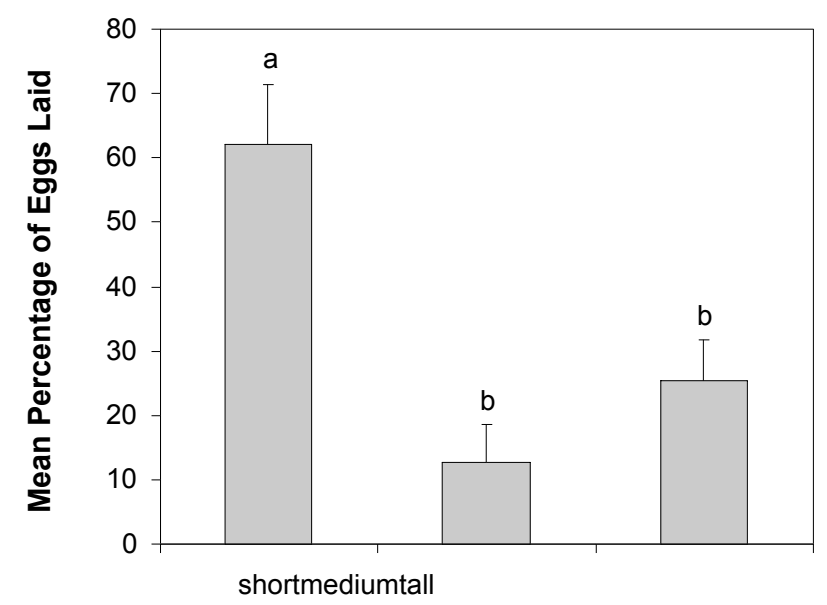

Grass Category

\section{Figure 3}

Mean percentages of eggs laid by wild-caught Anopheles gambiae s. I. in a choice-test of mud covered by three different heights of grasses. Bars topped with a common letter do not differ significantly at the 0.05 level (Tukey's HSD test). Error bars = S. E. M. The total number of eggs was 2393 for 180 female nights.

\section{Authors' contributions}

JH designed and carried out all the experiments, analysed and interpreted data, as well as drafted and revised the manuscript. EDW was P. I. of the grant supporting this work; he participated in the conception of the study, data collection and interpretation, and revision of the manuscript. PEO helped collect grass samples and data. FA identified grass species. JV provided institutional support for this study. JRM participated in the study design, data collection and interpretation, as well as drafting and revising the manuscript, and submitting the manuscript. All authors read and approved the final manuscript.

\section{Acknowledgements}

The authors thank Piera Siegert, Bill Morgan, and Blair Bullard (Michigan State University) for technical assistance. This study was funded by National Institute of Health grant Al50703.

\section{References}

I. Takken W, Knols BG]: Odour-mediated behavior of Afrotropical malaria mosquitoes. Ann Rev Entomol 1999, 44: I3I-I57.

2. Blackwell A, Johnson $S N$ : Electrophysiological investigation of larval water and potential oviposition chemo-attractants for Anopheles gambiae s. s. Ann Trop Med Parasit 2000, 94:389-398.

3. McCall P: Chemoecology of oviposition in insects of medical and veterinary importance. Blackwell Publishing, Berlin; 2002.

4. Huang J, Walker ED, Giroux PY, Vulule J, Miller JR: Ovipositional site selection by Anopheles gambiae: influences of substrate moisture and texture. Med Vet Entomol 2005, 19:442-450.

5. Huang J, Walker ED, Vulule J, Miller JR: The influence of darkness and visual contrast on oviposition by Anopheles gambiae in moist and dry substrates. Physiol Entomol 2006 in press.

6. Sumba LA, Guda TO, Deng AL, Hassanali A, Beier JC, Knols BGJ: Mediation of oviposition site selection in the Africa malaria mosquito Anopheles gambiae (Diptera: Culicidae) by semiochemicals of microbial origin. Int J Trop Insect Sci 2004, 24:260-265.

7. Huang J, Miller JR, Chen S, Vulule J, Walker ED: Anopheles gambiae (Diptera: Culicidae) oviposition in response to agarose media and cultured bacterial volatiles. J Med Entomol 2006, 43:498-504.

8. Russell PF, Rao TR: On relation of mechanical obstruction and shade to oviposition of Anopheles culicifacies. J Exp Zool 1942, 91:303-329.

9. Chandler JA, Highton RB: The succession of mosquito species (Diptera, Culicidae) in rice fields in the Kisumu area of Kenya, and their possible control. Bull Ent Res 1975, 65:295-302.

10. Orr BK, Resh VH: Influence of Myriophyllum aquaticum cover on Anopheles mosquito abundance, oviposition, and larval microhabitat. Oecologia 1992, 90:474-482.

II. Clements AN: The biology of mosquitoes. CABI Publishing, UK; 1999.

12. Minakawa N, Mutero CM, Githure JI, Beier JC, Yan G: Spatial distribution and habitat characterization of anopheline mosquito larvae in Western Kenya. Am J Trop Med Hyg 1999, 61:1010-1016.

13. Gimnig JE, Ombok M, Kamau L, Hawley WA: Characteristics of larval anopheline (Diptera: Culicidae) habitats in Western Kenya. J Med Entomol 200I, 38:282-288.

14. Mutuku FMM, Alaii JA, Bayoh N, Gimnig JE, Vulule JM, Walker ED, Kabiru E, Hawley WA: Distribution, description, and local knowledge of larval habitats of Anohpeles gambiae s. I. in a village in western Kenya. Am J Trop Med Hyg 2006, 74:44-53.

15. Mutuku FMM, Bayoh N, Gimnig JE, Vulule JM, Kamau L, Walker ED, Kabiru EW, Hawley WA: Pupal habitat productivity of Anopheles gambiae complex mosquitoes in a rural village in Western Kenya. Amer J Trop Med Hyg 2006, 74:54-6I.

16. Muirhead-Thomson RC: Studies on the breeding places and control of Anopheles gambiae and A. gambiae var. melas in 
coastal districts of Sierra Leone. Bull Entomol Res 1945 , 36: $185-252$.

17. Fillinger U, Sonye G, Killeen GF, Knols BG], Becker N: The practical importance of permanent and semipermanent habitats for controlling aquatic stages of Anopheles gambiae sensu lato mosquitoes: operational observations from a rural town in western Kenya. Trop Med Int Health 2004, 9: I274-I 289.

18. Minakawa N, Sonye G, Mogi M, Yan G: Habitat characteristics of Anopheles gambiae s. s. larvae in Kenyan highland. Med Vet Entomol 2004, 18:301-305.

19. SAS Institute: Guide for personal computers, Version 6 SAS Institute, Cary, NC; 1999.

20. Koenraadt CJM, Paaijmans KP, Githeko AK, Knols BGJ, Takken W: Egg hatching, Larval movement and larval survival of the malaria vector Anopheles gambiae in desiccating environments. Malar J 2003, 2:20.

21. Miller JR, Huang J, Vulule J, Walker ED: Life on the edge: African malaria mosquito larvae (Anopheles gambiae) are amphibious. Naturwissenschaften 2006 in press.

22. Holstein MH: Biology of Anopheles gambiae World Health Organization, Geneva, Switzerland; 1954.

Publish with Bio Med Central and every scientist can read your work free of charge

"BioMed Central will be the most significant development for disseminating the results of biomedical research in our lifetime. "

Sir Paul Nurse, Cancer Research UK

Your research papers will be:

- available free of charge to the entire biomedical community

- peer reviewed and published immediately upon acceptance

- cited in PubMed and archived on PubMed Central

- yours - you keep the copyright

Submit your manuscript here:

http://www.biomedcentral.com/info/publishing_adv.asp 